\title{
Geospatial Mapping of Singhbhum Shear Zone (SSZ) with Respect to Mineral Prospecting
}

\author{
Bijay Singh, Jimly Dowerah \\ University Department of Geology, Ranchi University, Ranchi, India \\ E-mail: bsingh6029@gmail.com,jdowerah@gmail.com \\ Received January 19, 2010; revised February 25, 2010; accepted March 2, 2010
}

\begin{abstract}
Singhbhum Shear Zone is a highly mineralized zone having variety of minerals, predominantly those of uranium, copper and some sulphide minerals. From Remote Sensing data it is possible to decipher the regional lithology, tectonic fabric and also the geomorphic details of a terrain which aid precisely in targeting of metals and minerals. Mapping of mineralized zones can be done using Geospatial Technology in a GIS platform. The present study includes creation of various maps like lithological map, geomorphological map, contours and slope map using satellite data like IRS LISS-IV and ASTER DEM which can be used to interprete and correlate the various mineral prospective zones in the study area. Even the alterations of the prevalent mineral zones can be mapped for further utilization strategies. The present work is based on the investigations being carried under ISRO-SAC Respond Project (Dept. of Space, Govt. of India SAC Code: OGP62, ISRO Code: $10 / 4 / 556)$.
\end{abstract}

Keywords: Singhbhum Shear Zone, Geospatial Mapping, Mineral Prospecting, Alterations, Sulphide Ores

\section{Introduction}

Mineral Exploration is not only highly imaginative and creative but a very costly activity as well. Much information about potential areas for mineral exploration can be provided by interpretation of surface features on aerial photographs and satellite images (Lilesand et al, 2007). From Remote Sensing data it is possible to decipher the regional lithology, tectonic fabric and also the geomorphic details of a terrain which aid precisely in targeting of metals and minerals. Usage of Geospatial Technology has enhanced the study of mineral exploration as geological maps can be easily integrated with other important details like geomorphology, structure, geophysical data etc.

Multispectral image analysis technique in the field of Geologic remote sensing has proved to be a potential technique for the information extraction process. Number of image analysis techniques are evolved and applied for optimization of information extraction process.

SSZ represents one of the most spectacular tectonic features is occurring in the Singhbhum Craton spread over Jharkhand and adjoining areas, marks the boundary between the two Archaean Cratons of Singhbhum Granite Batholith and the Iron Ore Group and the Proterozoic Mobile Belt in the north. SSZ is an arcuate belt of $200 \mathrm{~km}$ length and width varying between $1-25 \mathrm{kms}$. It is one of the most well known mineral abundant zones in the country and extensive mineral exploration has been carried out in this zone since a long time. The Central Indian Suture or the Satpura Mobile Belt continues across the Mahanadi fault to form the Northern Boundary of the Singhbhum craton. The mobile belt bends around the craton to merge with the Eastern Ghats Mobile Belt in the south. The latter overthrusts the Singhbhum craton at the Sukhinda thrust.

The study area falls in the SSZ and is extended between Tatanagar ( $\left.22^{\circ} 50^{\prime} \mathrm{N}: 86^{\circ} 10^{\prime} \mathrm{E}\right)$ and Bahragora $\left(22^{\circ} 16^{\prime} \mathrm{N}\right.$ : $\left.86^{\circ} 43^{\prime} \mathrm{E}\right)$ in the south east falling mostly in the Survey of India Toposheet no. J/2, 6, 7, 10 and 11, confined in the East Singhbhum of Jharkhand (Figure 1). The present work involves geospatial mapping of the study area on a GIS platform by interpreting multispectral satellite imagery.

\section{Geological Setting}

SSZ is a unique arcuate structure extending from Bahragora in east to Porahat in west. At the extreme west end it grades into high angle fault and extends upto the western margin of Bonai granite. Satellite imagery study sho- 
ws that beyond Bahragora in east, the arcuate southern continuation of the shear zone extends through Mayurbhanj to Sukinda thrust (Ramakrishnan and Vaidyanathan, 2008). The shear zone is characterized by extreme ductile shearing, multiple metasomatism, migmatisation and prominent mineralization of copper, uranium, tungsten and phosphate. The bulk of the shear zone material is made up of pelites and volcanic clastics, probably gener- ated during the Dhanjori and Koira depositional cycles. The shear zone is also characterized by abundance of ultramafic intrusions such as hornblende schists, talc schists, serpentinite and synkinematic body of serpentinised lherzolite with pyroxinite relics. The deformational history of this shear zone is highly complex marked by repeated phases of folding, mylonitisation and rotation of fabric (Figure 2).

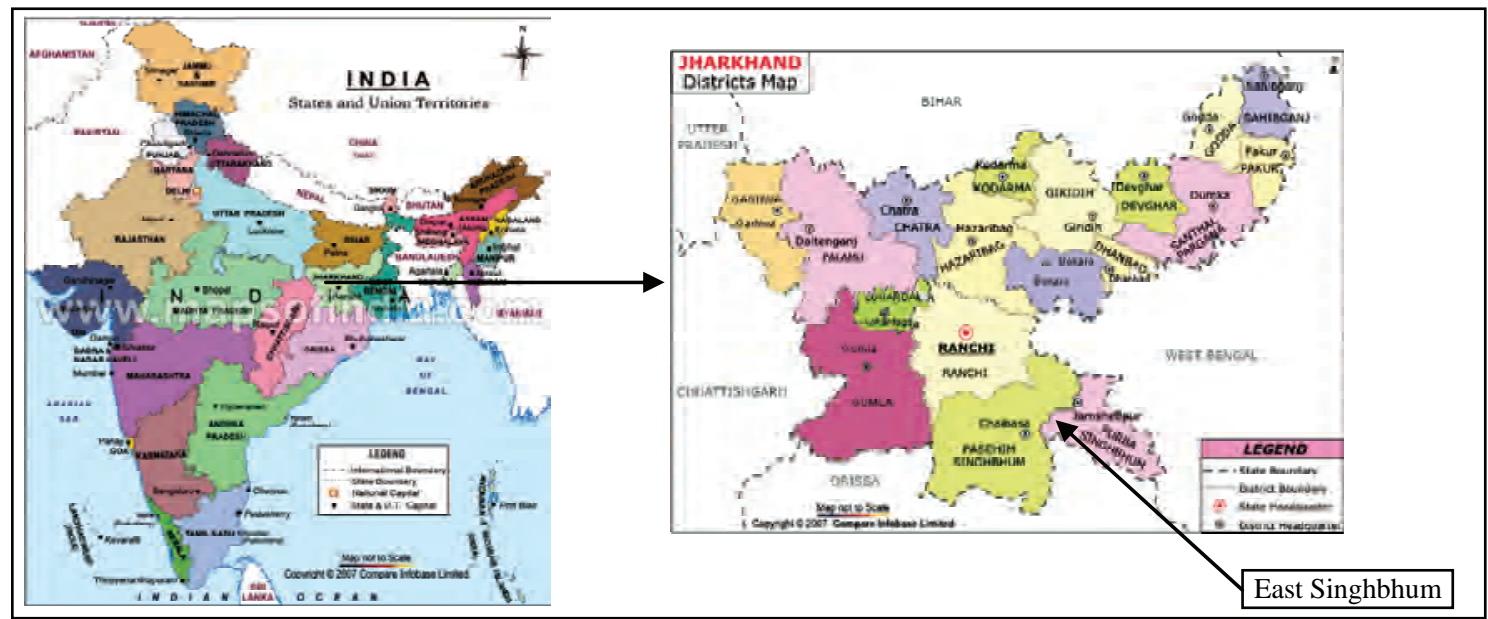

Figure 1. Location map.

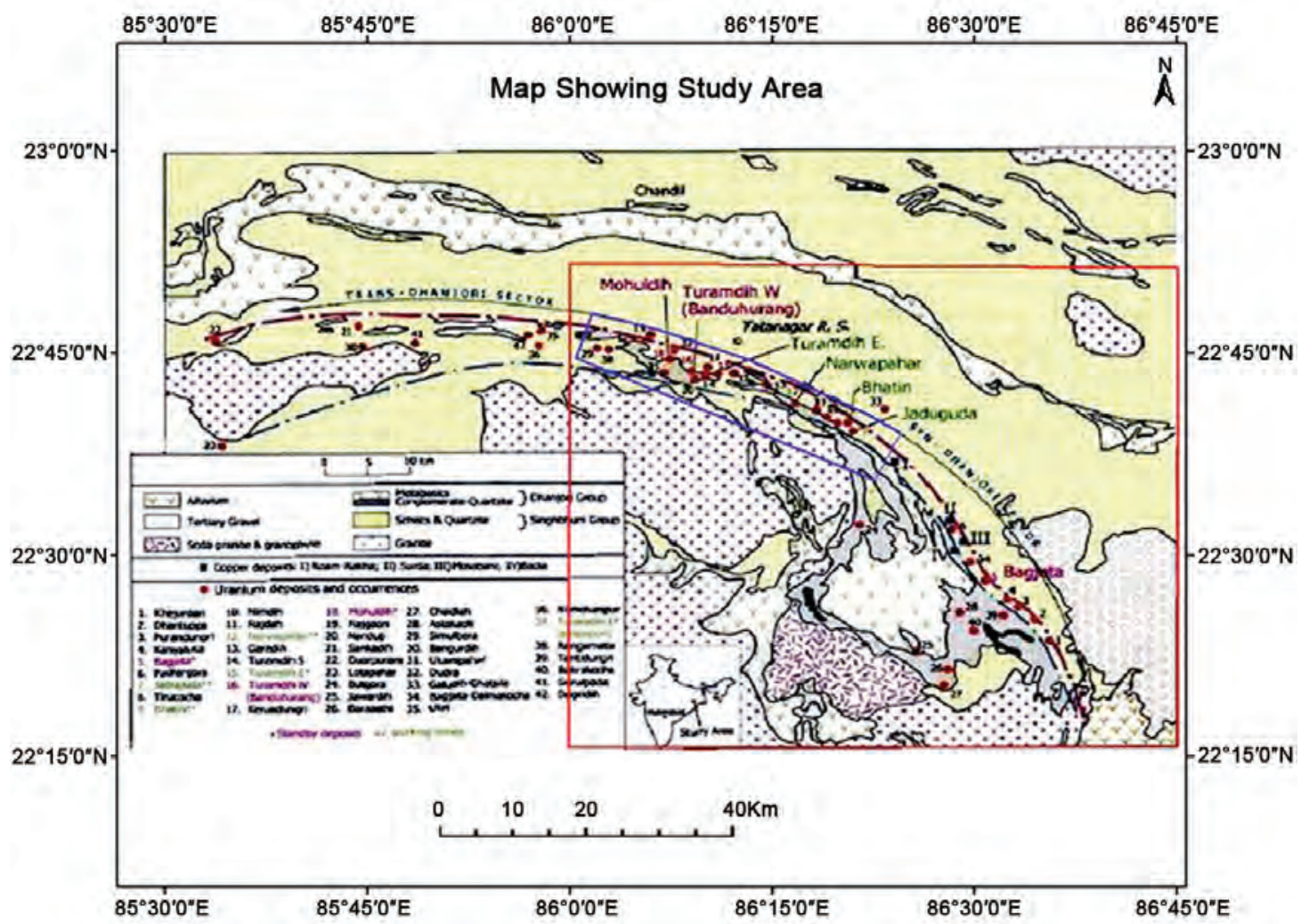

Figure 2. Geological map of Singhbhum shear zone (source: www.dae.gov.in/amd/regions). 


\section{Materials and Methods}

Data used: (see Table 1)

1) IRS LISS IV

2) ASTER DEM

3) Survey of India Toposheets

Software used:

1) ERDAS IMAGINE

2) Arc GIS 9.3

The methodology used in the present study in shown in the following Flow Figure 3.
Table 1. Specifications of LISS IV.

\begin{tabular}{ll}
\hline Ground Resolution & $5.8 \mathrm{~m}$ \\
\hline Steerability & Yes \\
Swath & $23.5 \mathrm{~km}(\mathrm{MX}), 70 \mathrm{~km}$ (MONO) \\
& $\mathrm{B}_{2}$ (green, 520-570 nm), \\
& $\mathrm{B}_{3}($ red, $630-700 \mathrm{~nm})$, \\
Spectral Bands & $\mathrm{B}_{4}(\mathrm{NIR}, 700 \mathrm{~nm}-1400 \mathrm{~nm})$ \\
& 7 bits selected out of 10 \\
Radiometric Resolution(Bits) & $5.8 \mathrm{~m}$ \\
IGFOV & $>128$ \\
SNR@Saturation & $>20$ all bands \\
SWR@Nyquist & $+/-26^{\circ}$ \\
Off Nadir Viewing &
\end{tabular}

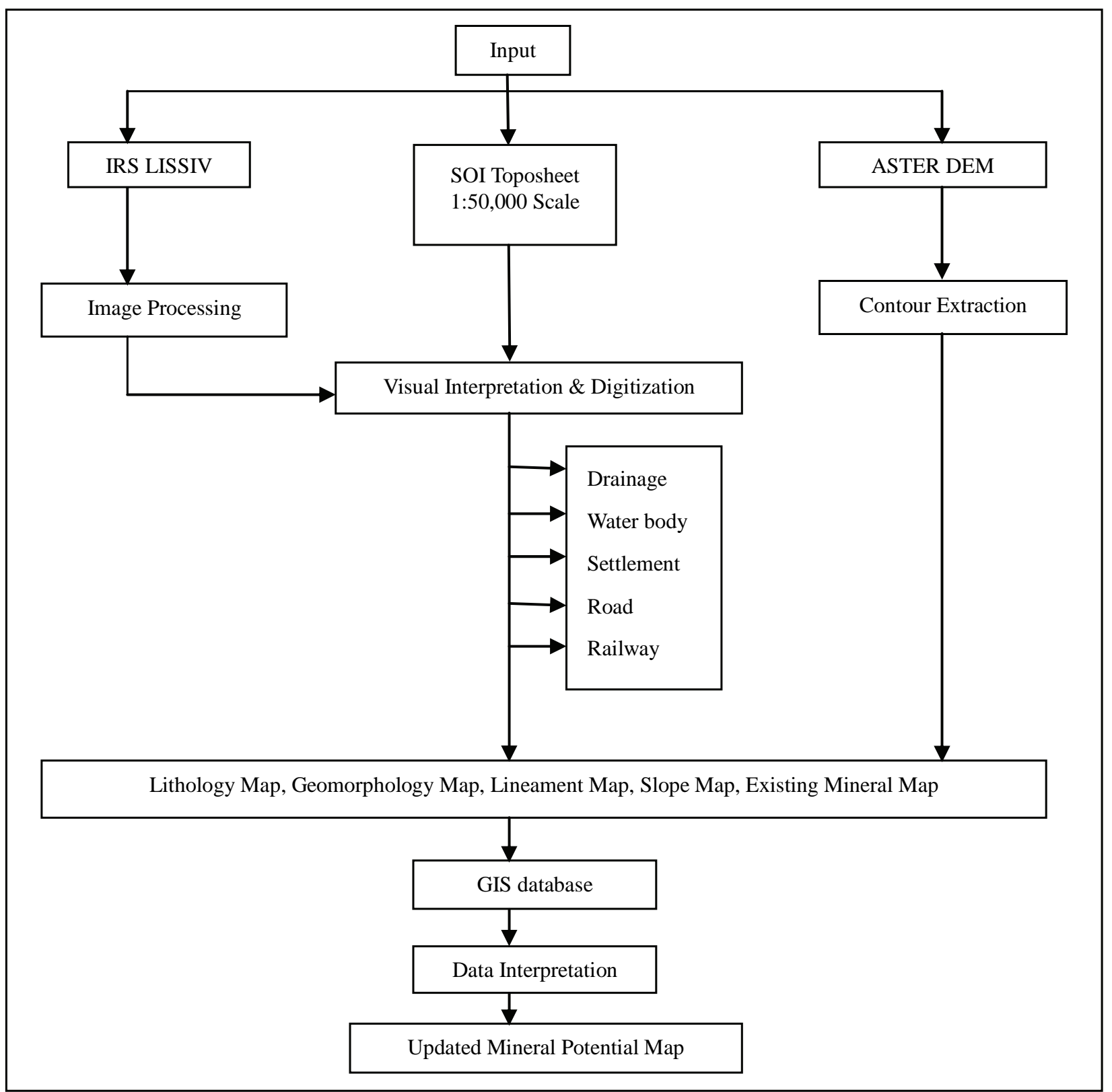

Figure 3. Flowchart showing methodology. 


\section{Generation of Maps}

The capability of GIS to manipulate classified spatial information through amalgamated layers makes it a unique tool for delineating potential locales. Flexibility of experimenting with spatial data followed by visualization of its effect immediately gives GIS a cutting edge over other contemporary techniques for modeling mineral deposits. For the preparation of GIS map, the data sets are grouped into polygon, line and point features depending upon the geographic distribution. The areas having aerial extent are taken as polygon layers; line features are digitized as line coverages.

In the present study, apart from the base map of the study area, Drainage map was prepared with the help of the LISS IV data (Figure 4). The contour lines at $50 \mathrm{~m}$ intervals were extracted from the ASTER DEM and the slope map (Figure 7) of the area was generated from it. The Geomorphological units were interpreted from the LISS IV imagery after processing the imagery and then with the help of the image interpretation keys like tone, texture, pattern, association and by relating to the lithology and height information of that particular area..

\section{Geomorphology}

Geomorphology serves as an excellent tool in economic geological point of view and aim in search of mineral deposits, the topographic expression gives clue to the geologic structure which is favourable for mineral deposits and indirect inference of geomorphic details of an area. It includes surface expression of the ore bodies like ridges, plateaus or some elevated position, which are indications of gossans and residual mineral occurring in weathering surface. Geomorphology not only gives the pattern and the spatial distribution of various landforms but also gives information on the natural resource potential. Such maps are graphic representation of landforms of an area. For mineral exploration, the geomorphic features are important in prospecting; the deposits formed by residual

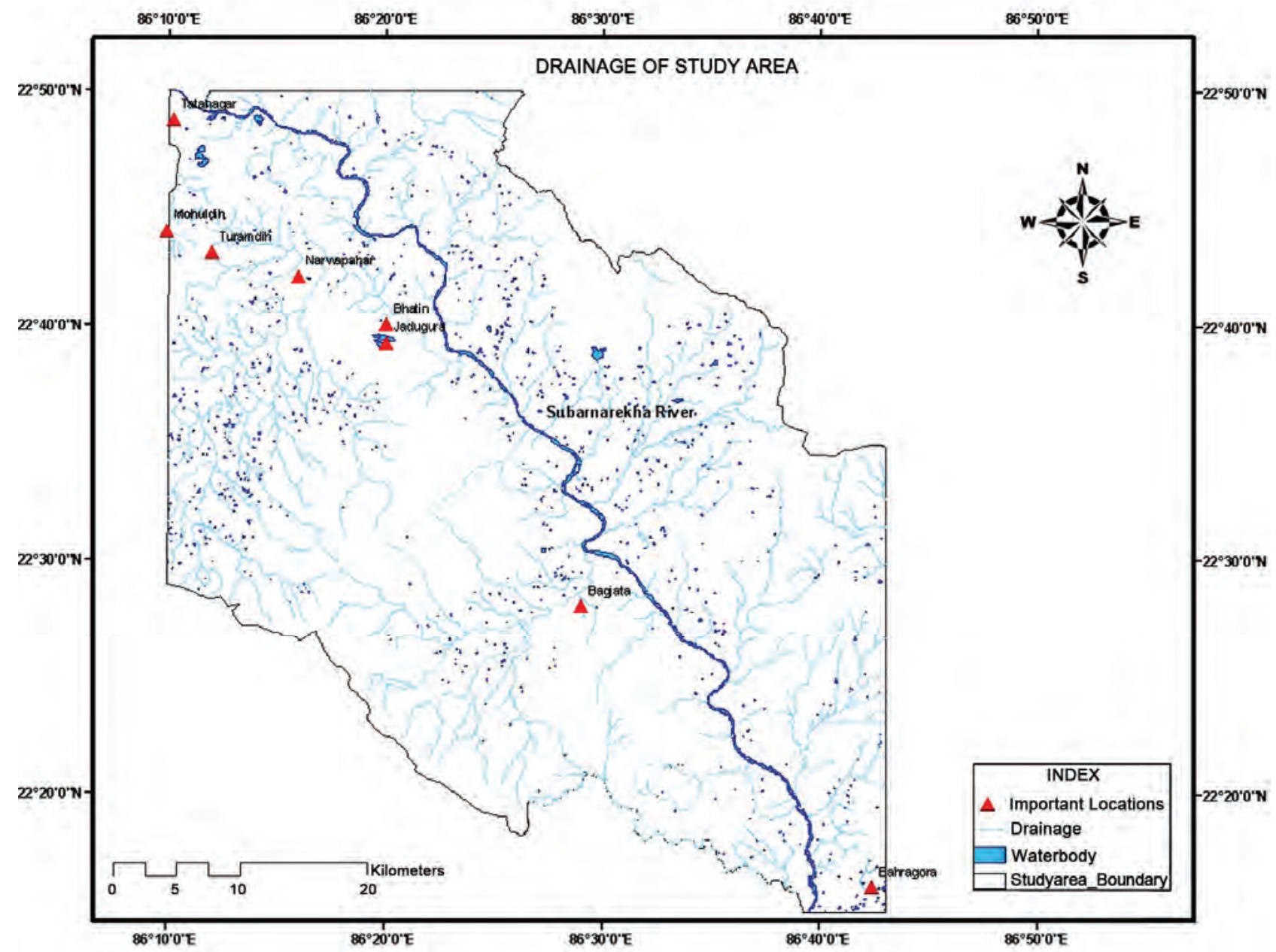

Figure 4. Drainage map of the study area. 
and supergene enrichment can be indicated. (E.g. hill slopes, ridges, plateaus and valleys etc) Alluvial plain, denudational hill, intermontane valley, pediment-inselberg complex, pediplain, pediment, undissected plateau, residual hill, structural hill, valley fill, water body and river sand make up the geomorphology of the study area. Pediplain covers $49.51 \%$ i.e. the majority of the area whereas least area is covered by undissected plateau $(0.28 \%)$. The Shear Zone is mainly covered by structural hill with intermontane valley in between and pediment and pediplain adjacent to it (Figure 5).

\section{Lithology}

Lithological maps can be easily integrated with other important details like geomorphology, structure, etc. This kind of data integration facilitates for the better identification of mineralized zones. The lithology of the study area is made up of talc-chlorite schists, phyllite, granite, quartzite, migmatite, mica-schist, laterite, hornblende schist, dolerite, epidiorite, gabbro anthracite, sandstone and alluvium. Mica/ Hornblende Schist with Phyllite bands occupy the largest area with $15.34 \%$ whereas sand/silt dominant alluvium covers the least area with $0.36 \%$.The lithology in the Shear Zone is mainly of Quartzite and Mica schist with phyllite adjacent to it (Figure 6).

\section{DEM}

DEM is created and the same is wrapped with digital FCC data. It gives a 3D view (Figure 8) of the landscape from which precise mapping can be interpreted perfectly. DEM wrapped various thematic layers can be used to prepare probable mineralized zones.

\section{Identification of Potential Mineralized Zones}

Mineral Resource Potential Mapping is a very complex analytical procedure which requires simultaneous consideration of a number of spatial evidences-geological, geomorphological, structural etc. In the present study, geomorphology and lithology has been mapped and observations have been made based on it. As quartzite dominates the lithology of the Shear Zone, it can be said that the area contains zircon, rutile as minerals. Zircon is known to contain uranium and rutile is mainly composed of titanium. Natural rutile also contains significant amount of niobium and tantalum. The presence of phyllite in the shear zone indicates quartz, sericite content. Sericite is a common alteration mineral of orthoclase or plagioclase feldspars in areas that have been subjected to hydrothermal alteration typically associated with copper, tin, or other hydrothermal ore deposits.

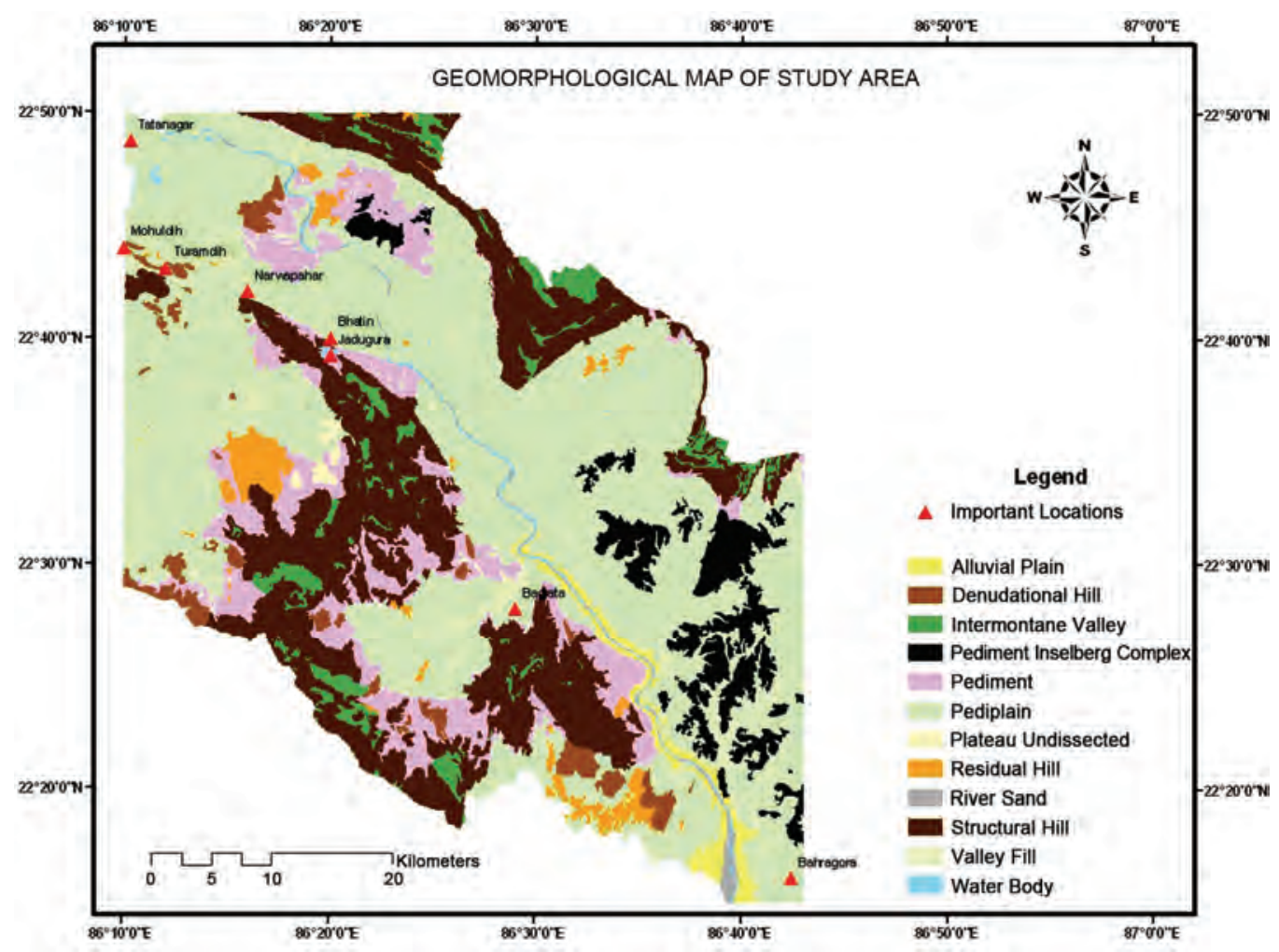

Figure 5. Geomorphological map of the study area. 


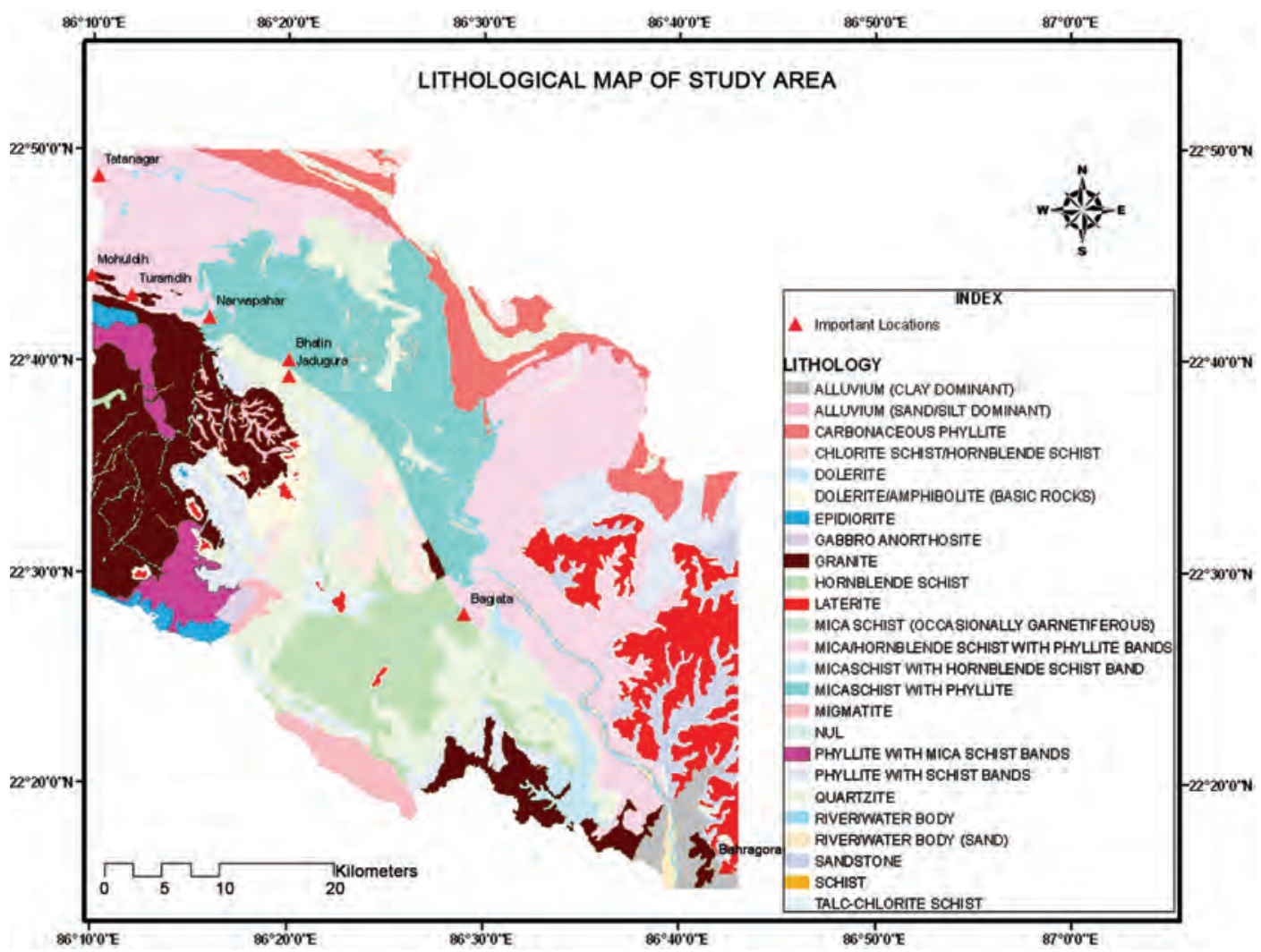

Figure 6. Lithological map of study area,

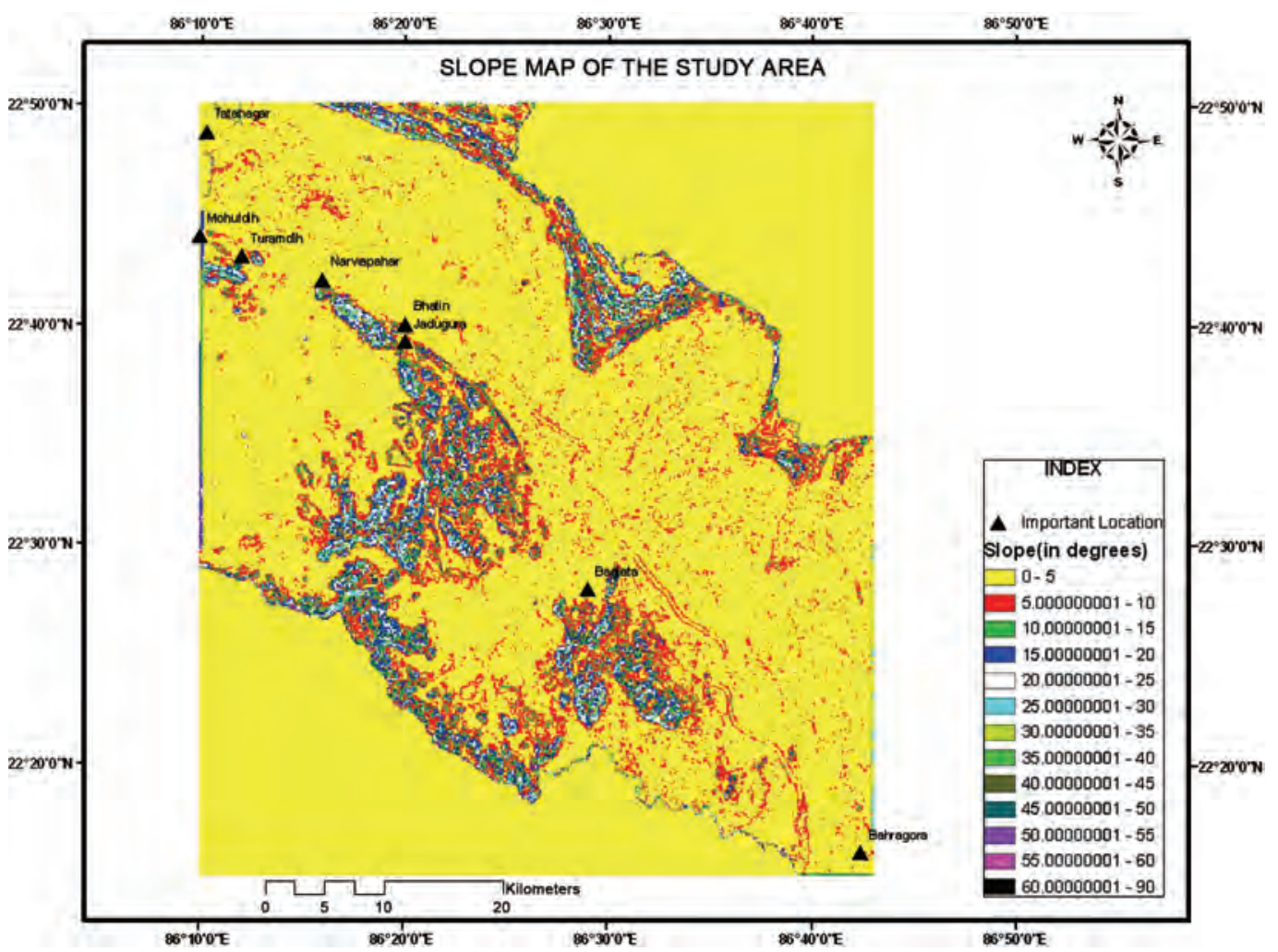

Figure 7. Slope map of the study area. 


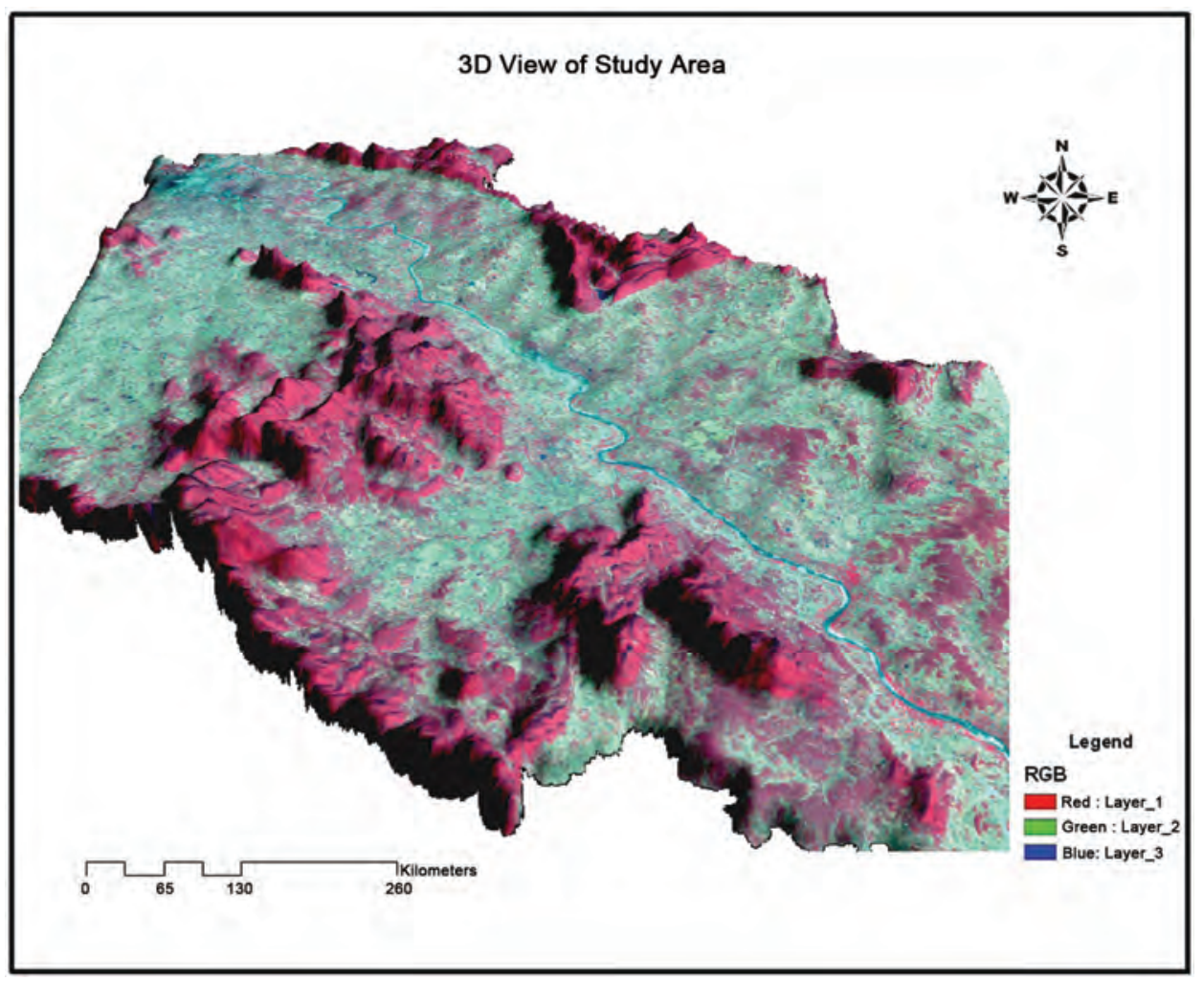

Figure 8. 3D view of study area.

The probability of occurrence of minerals as mentioned above is based on the lithology and related geomorphology. Further studies based on alteration zone, lineament mapping will make it more specific as lineaments can help to spot the location of mineral abundance and so can alteration zones.

\section{Summary and Conclusions}

Geospatial Mapping for complex regions like Singhbhum Shear Zone is an important activity since it involves a detailed information database through the satellite based studies. These informations have to be generated for an integrated regional development approach for this strategic location. Presently the LISS-IV imagery has been utilized to prepare an updated host of geological maps like geomorphology, slope, drainage, base map. The drainage pattern of the area provides clue about the bedrock lithology, topography and the types of landform present. In the present area, the drainage pattern is seen to be dendritic. The delineation of geomorphological units suggest that the landform class in the study region is that of landform developed on folded strata whereas the adjacent areas have a fluvial landform (after landform classification by Rasher and Weaver, 1990). Due to a hostile and inaccessible area these maps are highly useful for further investigations and interpretations to be used by the mining industries especially Uranium Corporation of India Limited (UCIL), Indian Copper Complex (ICC) for their optimum utilization and the Government and NGOs to take advantage for their need based planning and programmes. The various geomorphological units and their features are attempted to delineate the adjacent viable mining areas and their potential estimation. The factors responsible for contamination of the local water bodies with the radiogenic environment and their side effects are also being investigated on the basis of these maps.

\section{Acknowledgements}

The authors wish to acknowledge the Head of the Dept. of Geology, Ranchi University for his support and motivation. Dr. A. T. Jeyaseelan, Director, JSAC is sincerely acknowledged for his kind permission to avail the lab facilities at JSAC under his guidance. The Focal Person of the ISRO-SAC RESPOND Project (SAC code: 0GP62, ISRO code: 10/4/556) is also gratefully acknowledged for his motivation and academic comments.

\section{References}

[1] T. S. Balakrishnan, P. Unnikrishnan and A. V. S. Murty, "The Tectonic Map of India and Contiguous Areas," 
Journal of the Geological Society of India, Vol. 74, 2009, pp. 158-170.

[2] T. K. Bhattacharya, A. V. Sankaran and S. R. Shivananda, "Observations on Uranium Mineralization in Jaduguda and Other Places of Singhbhum Thrust Belt," Symposium on Uranium Prospect in India, Jaduguda Mines Project, Bihar, 1996, pp. 78-88.

[3] J. A. Dunn, "The Geology of North Singhbhum including Parts of Ranchi and Manbhum Districts," Memoir Geological Survey of India, Vol. 54, No. 2, 1929, pp. 1-166.

[4] J. A. Dunn and A. K. Dey, "Geology and Petrology of Eastern Singhbhum and Surrounding Areas," Memoir Geological Survey of India, Vol. 69, No. 2, 1942, pp. 281-456.

[5] T. M. Lillesand and R. W. Kiefer, "Remote Sensing and Image Interpretation,” 6th Edition, John Wiley \& Sons, New York, 2007, pp.10-15.

[6] S. Mishra, "Precambrian Chronostratigraphic Growth of Singhbhum Orissa Craton, Eastern Indian Shield: An Alternative Model," Journal of the Geological Society of India, Vol. 67, 2006, pp. 356-378

[7] B. Mukhopadhyay, N. Hazra, S. R. Sengupta and S. K. Das, "Mineral Potential Map by Knowledge Driven GIS
Modeling: An Example from Singhbhum Copper Belt, Jharkhand”. http://www.gisdevelopment.net/Application/ Geology

[8] D. Mukhopadhyay and G. K. Deb, "Structural and Textural Development in Singhbhum Shear Zone, Eastern India,” Proceedings of the Indian Academy of Sciences, Vol. 104, No. 3, 1995, pp. 385-408.

[9] S. Rajendran, et al. (Eds.) "Mineral Exploration: Recent Strategies,” New India Publishing Agency, New Delhi, 2007, pp. 49-61.

[10] M. Ramakrishnan and R. Vaidyanathan, "Geology of India,” Geological Society of India, Bangalore, Vol. 1, 2008, pp. 232-233.

[11] B. Singh and J. Dowerah, "RS-GIS Based Strategies for Mineral Targetting in Parts of Singhbhum Shear Zone, Jharkhand," Vistas in Geological Research U. U. Spl. Publ. in Geology Vol. 8, 2009, pp. 81-86.

[12] K. K. Sinha, N. K. Rao, V. L. Saha and T. S. Sunilkumar, "Stratigraphic Succession of Precambrian of Singhbhum: Evidence from Quartz-Pebble-Conglomerate,” Journal of the Geological Society of India, Vol. 49, 1997, pp. 577-588. 